\title{
The Impact of Guiding Materials on Students' Conceptual Understanding: The Case of "What Is the Earth's Crust Composed of?"*
}

\author{
Tülay Şenel Çoruhlu ${ }^{1}$, Sibel Er Nas ${ }^{1}$ \\ ${ }^{1}$ Karadeniz Technical University, Fatih Faculty of Education, Trabzon/Turkey \\ Correspondence: Sibel Er Nas, Karadeniz Technical University, Fatih Faculty of Education, Trabzon, Turkey.
}

Received: December 14, 2016

Accepted: January 13, 2017

Online Published: January 19, 2017

doi:10.11114/jets.v5i2.2169

URL: http://dx.doi.org/10.11114/jets.v5i2.2169

\begin{abstract}
The aim of this research is to determine the effect of the use of guidance material based on the 5E model on students' conceptual understanding of a topic entitled "What is the earth's crust composed of?". The sample consists of 40 students from the 5th grade (experimental group 20, control group 20). A concept test, a drawing test, and semi-structured interview questions were used for data collection. In the experiment group, guidance material prepared according to the $5 \mathrm{E}$ model was used; the control group was conducted using the existing textbook. Student responses were examined in terms of the following categories: complete understanding, partial understanding, alternative concept, no response or irrelevant responses. The quantitative data obtained from the experimental and the control groups were compared by using the Mann-Whitney U-test. Content analysis was used to analyze students' drawings. In conclusion, it was determined that the guidance materials developed according to $5 \mathrm{E}$ model have a positive effect $(U=76.00, p<.05)$ on students' conceptual understanding about the topic entitled "What is the earth's crust composed of?".
\end{abstract}

Keywords: "What is the earth's crust composed of?" topic, guidance material, conceptual understanding

\section{Introduction}

In Turkey, one of the reasons noted for the lack of interest in science classes in school lies in the failure to establish a connection with daily life (Dervişoğlu, Yaman \& Soran, 2004). As long as the students can associate what they learn in science classes with daily life, they will be able to much more easily interpret the new circumstances they face (Er Nas, Şenel Çoruhlu \& Kirman Bilgin, 2016). Science classes are closely associated with the lives of individuals. Yet, studies so far reveal that the emphasis on the relationship between the concepts taught in schools and the events of daily life is not sufficiently well established (Barker \& Millar, 1999; Yager \& Weld, 1999). The science curriculum in Turkey is based on inquiry, which in turn is based on instruction strategy (Ministry of National Education [MoNE], 2013). On the other hand, the curriculum does not stipulate a specific teaching model, and leaves the choice of teaching model to the discretion of the teacher. This is why teachers need teaching approaches that have been developed within the framework of the learning theory of choice. In the present study, guidance materials to match the approach adopted in the curriculum have been developed in line with the $5 \mathrm{E}$ model. A number of models such as $4 \mathrm{E}, 5 \mathrm{E}$ and $7 \mathrm{E}$ have been employed for the application of constructivist learning theory in actual learning environments. In the present study, the $5 \mathrm{E}$ model was deemed to be most effective, given the 7E model's perceived complexity in the eyes of teachers, and the lack of deepening step in the 4E model (Treagust, Harrison \& Venville, 1998). The 5E model is seen to contribute positively to attracting the students' attention to the course, making the learning environment more enjoyable (Özsevgeç, 2006), eliminating students misconceptions (Özsevgeç, 2006; Şahin, İpek Akbulut \& Çepni, 2012; Şenel Çoruhlu, Kirman Bilgin \& Er Nas, 2016) and increasing students' achievement levels (Hançer, 2006; Özsevgeç, 2006; Çardak, Dikmenli \& Sarıtaş, 2008; Patro, 2008; Anil \& Batdi, 2015). The topics covered in the "Mystery of Earth's Crust" unit are taught in the 5th year of the science curriculum for the year 2013. A glance at the literature reveals that the students have certain misconceptions regarding concepts such as the rock cycle (Blake, 2004; Rosenberg, Hammer \& Phelan 2006), rocks and minerals (Ford, 2005), the formation of rocks (Dal, 2009), ground waters (Reinfried 2006), fossils (Dal, 2007), and erosion (Dove, 1997; Bozkurt, Salman Akın \& Usak, 2004; Alım, Özdemir \& Yılar, 2008; Ateş, 2013; Özgen,

\footnotetext{
*This study has been produced from the data obtained in the framework of the project with code 12462 supported by the Karadeniz Technical University, Scientific Research Project (BAP).
} 
2013). A review of the literature leads to the conclusion that most of the studies on the topics covered by the "Mystery of Earth's Crust" unit focus on identifying students' misconceptions (Blake, 2004; Dal, 2007; Ford, 2005; Reinfried 2006; Rosenberg, Hammer \& Phelan 2006; Dove, 1997; Blake, 2005; Dal, 2007; Dal, 2009; Özgen, 2013; Turan \& Kartal, 2012), while those studies which delve into the question of how to eliminate such conceptions (Blake, 2004) did not exist. Furthermore, the samples used in the studies make it clear that various misconceptions exist among students from primary school (Bozkurt, Salman Akın \& Uşak 2004; Ford, 2005) to university level (Dal, 2007; Dal, 2009; Özgen, 2013).

The efforts to find a study which employed the $5 \mathrm{E}$ model on the 5 th year of primary education with respect to the "What is the Earth's Crust Composed of?" topic covered in the "Mystery of Earth's Crust" unit, investigating the effectiveness of the said model, did not yield any results. The present study utilizes the conceptual change texts, case studies, and worksheets entailed in the 5E model. The case study method refers to the establishment of a link between the concept being learned and the situation the concept arises in. This method makes it possible to find solutions at the classroom level, for problems faced in real life (Demirel, 2014). Case studies may refer to real life events, or be figments of imagination. Regardless, a useful case to be studied should reflect reality (Küçükahmet, 2000) and attract the attention of students (Chambers \& Andre, 1997). Conceptual change texts are among the pedagogical tools employed to replace students' misconceptions with scientific truths. Conceptual change texts contribute to meaningful learning on the part of the student (Duit, 1991). Worksheets, on the other hand, are written materials covering the activities the students will engage in during the teaching of a given topic, as well as the written statements regarding those activities (Harlen, 1996), and can be used in the teaching of concepts. It is evident that the science curriculum emphasizes the students' ability to provide explanations for cases they come across in their daily lives (MoNE, 2013). That is why the materials to be developed within the framework of the $5 \mathrm{E}$ model will be crucial for both teachers and students.

There is limited research in the literature regarding the topic "What is the Earth's Crust Composed of?" in terms of investigating the impact on the conceptual understanding on the part of the students. This study will help cover a gap in the literature. Furthermore, the guidance materials to be developed in line with the $5 \mathrm{E}$ model are expected to provide guidance for science teachers. It is well known that non-scientific knowledge acquired in early life has a negative impact on future learning and intervention early on at the primary school level could be particularly effective in terms of overcoming misconceptions. This study will contribute to the elimination of the misconceptions students harbor with respect to the new topic "What is the Earth's Crust Composed of?" which is new to them. It is believed that the students would therefore be able to base their future learning on solid grounds.

The aim of this study is to develop guidance materials based on the $5 \mathrm{E}$ model, for the topic "What is the Earth's Crust Composed of?" and to investigate the impact of such guidance materials on students' conceptual understanding.

\section{Method}

A quasi-experimental method ("pre-test-post-test" with control group) was used for the study. This method is the preferred method in educational research. The groups were established using non-random selection (Tharenou, Donohue \& Cooper, 2007). With the quasi-experimental method, students were grouped into experimental and control groups after being assigned in an equitable way (Büyüköztürk, 2004).

\subsection{Sample}

The population consisted of 5th grade students from Trabzon city in Turkey. The sample size was 40 students. There was one control group of 20 students - 11 girls and 9 boys, with a mean age of 11.74 years, and one experimental group of 20 students -12 girls and 8 boys with a mean age of 12.06 years. Two voluntary teachers in the same school graduates of Karadeniz Technical University - participated in the research. The experimental group teacher had 6 years' experience and the control group teacher had 10 years' experience. The materials which were used in the experimental group was introduced to the teacher by the researchers prior to the intervention. Each teacher completed the application process in their classes in 8 lesson hours.

\subsection{Data Collection Tools}

A concept test, an interview consisting of semi-structured questions, and a drawing test were utilized to collect data. Students were asked three open-ended questions in the concept test as follows:

1. How would you define the concepts of rock and mine? Please explain.

2. How would you define the concept of a fossil? Please explain.

3. How would you define the concept of natural monument? Please explain.

To enhance the content and validity of the tests, data were evaluated by one science educator and two science teachers.

To measure the reliability of the concept and drawing tests, the tests were implemented by 12 grade 6 students who 
learned these concepts in the 5th grade. The concept test was administered one week prior to the intervention as a pre-test to both the experimental and the control groups. The pre-test was employed as a post-test, immediately after the intervention.

The first version of the concept test included 4 open-ended questions. The second question is related to the definition of the concept of fossil, while the third question is related to the formation of the fossil. Students gave similar answers to these questions. The second and third questions in the concept test were combined as follows: "How would you define the concept of a fossil? Please explain".

Drawings make very few restrictions on the responses of the students (White \& Gunstone, 1992). Therefore, besides a concept test, a drawing test was used in this research. Drawings can be much more valuable than words by providing detailed information information (Sheppard, 2006). The tasks given to the students were as follows: 1. Please draw a figure to describe what the concept of fossil means for you.

2. Please draw a figure that describes what natural monuments mean to you.

To measure the reliability of the drawing test, it was implemented with $126^{\text {th }}$ grade students who had learned these concepts in the 5th grade. The drawing test was administered one week prior to the intervention as a pre-test to both the experimental and the control groups. The same test was employed as a post-test immediately after the intervention with these groups.

The interviews were conducted with semi-structured questions. Participants were interviewed individually with 10 of the experimental group (E2, E3, E6, E8, E10, E13, E14, E16, E17, and E19) to investigate the effectiveness of the materials on the students' conceptual understanding of the new topic. The same questions used in the concept test were used in this part of the study. Semi-structured interview questions were administered one week prior to the intervention as a pre-interview to 10 of the experimental group students. The same questions were used immediately after the intervention. The questions were evaluated by one science educator and one science teacher to enhance their validity. To measure the reliability of the questions, the questions were developed with $26^{\text {th }}$ grade students. The interviews were recorded. Each interview lasted approximately 8-12 minutes in the pre-intervention and 10-15 minutes in the post-intervention.

2.3 Data Analysis

Marek's (1986) categorization was used to analyze the concept test and interview responses. (see Table 1).

Table 1. Categories using in the analysis of the concept test and interviews

\begin{tabular}{lll}
\hline Categories & Code & Point \\
\hline Complete understanding & A & 3 \\
Partial understanding & B & 2 \\
Alternative concept & C & 1 \\
No response or irrelevant responses & D & 0 \\
\hline
\end{tabular}

The data obtained from the experiment and control groups were compared by utilizing the Mann-Whitney U-test. The drawing test was analyzed using content analysis. The students' drawings were examined in detail and categorized. Categories with their frequency values were presented in a table form. Also, samples from student drawings were presented in the tables. Students were coded in line with research ethics. For instance, student number 1 from the experimental group has been shown as $\mathrm{E} 1_{\mathrm{PT}}$ in the pre-test and as $\mathrm{E} 1_{\mathrm{LT}}$ in the post test. Student number 2 from the control group was coded similarly as $\mathrm{C} 22_{\mathrm{PT}}$ and $\mathrm{C} 2 \mathrm{LT}_{\mathrm{LT}}$.

\subsection{Material Application Process}

The guidance material developed based on the 5E model (Engage, Explore, Explain, Elaborate, and Evaluate) for the concepts covered by the topic "What is the Earth's Crust Composed of?" in the science curriculum, and applied to the experimental group, is described below. The application process was completed within 8 hours of classroom activity, as provided in the curriculum. The control group, on the other hand, made use of the existing textbook in a process also completed in 8 hours (Bayram \& Kibar, 2014). The work carried out with regard to each step of the material based on the $5 \mathrm{E}$ model, and applied to the experimental group, were summarized below. The images used in the materials were downloaded from the Google.

One of the materials used in the Engaged step was a case study entitled "Mines". The aim of the case study was to attract the students' attention to the topic. 


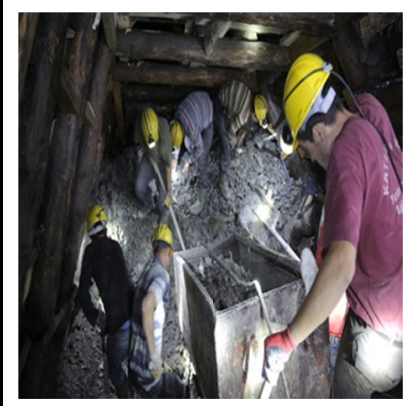

CASE STUDY: MINES

Ahmet had just arrived home. His mom and dad were glued to the TV in total bewilderment. The newscaster is reading the news "Unbearable picture of mining accidents... Since 1941 more than three thousand miners have died in various occupational accidents. Furthermore, more than 100,000 have been injured in such accidents." Ahmet turns to his father and asks "What is a mine?". His father tries to explain the concept of a mine and their importance for the national economy.

Ahmet then asks "Why do accidents happen at mines?" His father responds by saying that the accidents are due to a variety of reasons including inadequate safety measures and escape routes.

\section{Questions}

1. What is the relationship between the concepts of rock and mine?

2. What are the causes of mining accidents?

3. What kind of measures can be taken to prevent mining accidents occurring in Turkey?

4. Why do we use mines? What are their contributions to technology?

\section{Figure 1. Material used in the Engage step}

One of the materials used in the Explore step is the worksheet entitled "How do fossils form?". The worksheet aims to ensure the students' active involvement in the learning process.

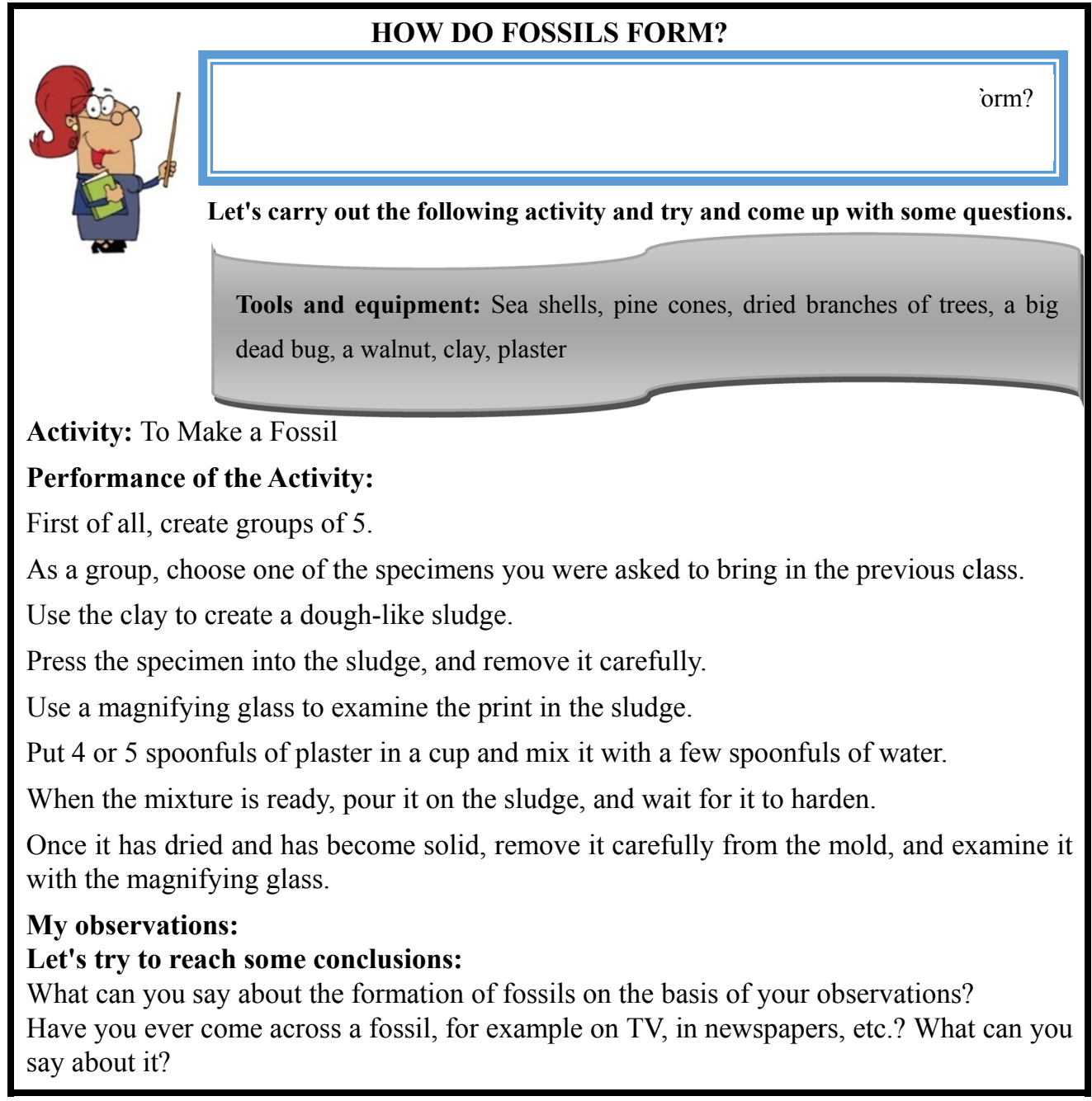

Figure 2. Material used in the Explore step 
One of the materials used in the Explain step is the conceptual change text entitled "Fossils". These texts aimed to ensure the students' active involvement in the learning process.

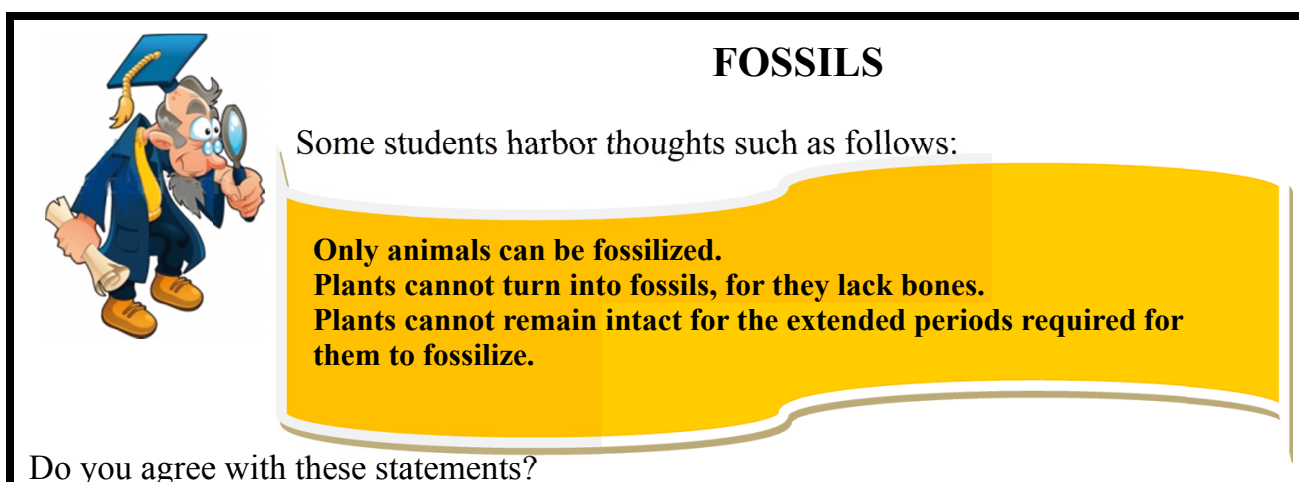

Do you agree with these statements?

\section{Now, let's read the following text.}

This will give us some correct ideas about fossils.

The remnants of plants and animals which inhabited the world in the past, and are preserved in rocks, are called fossils. The living things which died can sometimes be preserved in

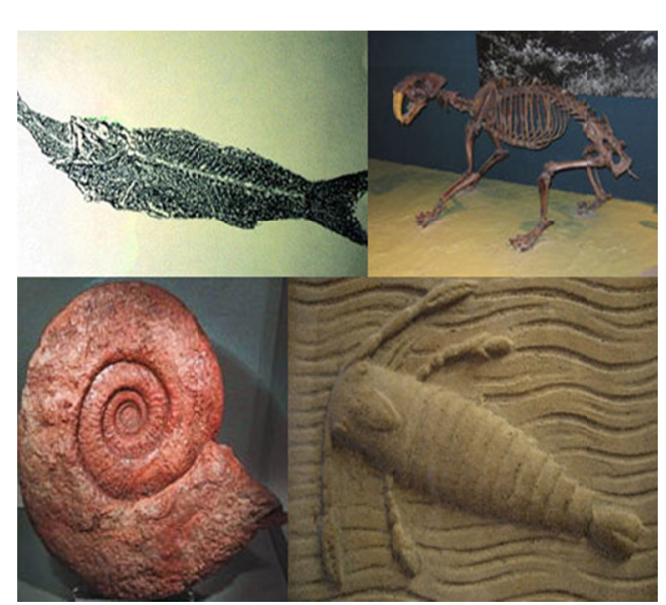
sedimentary rocks in the earth's crust. After the living thing dies, rivers, streams, and winds carry stones and soil and cover the creature. In due time, the layers that accumulate on the remnants of the once-living thing get thicker, as well as more numerous, with the addition of further layers. The layers on top apply pressure on the lower ones, and ensure the hardening of the bottom layers, turning them into rocks. Sedimentary rocks are formed through this process, while preserving the remnants of the once-living thing in them. The sedimentary rocks thus formed can later on move to the upper levels of the earth's crust, thanks to tectonic activity and erosion.

The categorization of fossils with reference to their formation refers to bone fossils as well as trace fossils, petrified fossils, and carbonized fossils. Often, bone fossils are formed by the remnants of the bone structures and the teeth of the living things, while carbonized fossils are formed as remnants of plants that become buried deep in seas, lakes, or marshes.

Congratulations... Now you have learned

* That both plants and animals can be fossilized,

* How fossils form,

* That fossils are not merely bone remnants.

Figure 3. Material used in the Explain step

One of the materials used in the Elaborate step is a case study entitled "Travertines of Pamukkale are in Danger". The case study aims to help students associate what they have learned in their daily lives. 


\section{TRAVERTINES OF PAMUKKALE ARE IN DANGER!}

When watching TV, Zeynep Elvin noticed a news item. The headline was "Travertines of

Pamukkale are in Danger!". The news item reported that tourists visiting the travertines have inadvertently polluted them. In particular, the report stated that visits by tourists caused damage to the lime surfaces of the travertines, while the waste left by tourists contributed to the pollution of the waters. Zeynep Elvin turned to her father and asked "What can we do to prevent damage to the travertines?". His father, in turn, gave her a detailed answer.

What do you think Zeynep Elvin's dad recommended to prevent further damage to the travertines?

Figure 4. Material used in the Elaborate step

One of the materials used in the Evaluate step was the concept map. The students were asked to fill out the relevant fields on the concept map. The aim with regard to using the concept map was to evaluate the level of achievement on the part of the students with respect to the learning outcomes envisaged in the course.

\subsection{Control Group Application Process}

The control group used the existing textbook developed on the basis of the inquiry which was based on the instruction strategy as noted in the science curriculum. The control group also dealt with the topic "What is the Earth's Crust Composed of?" for 8 hours. Let us try and summarize the process of teaching the "Get to know the earth's crust and rocks" sub-topic as an example. In this context, what a rock meant was first described, followed by the activity "Let's examine the stones". The activity was followed in turn by a news item in the "Information Column". The students learned about minerals, fossils and natural monuments. Finally, the "Let's Research and Learn" section asked students to obtain information about mines, fossils and natural monuments. Students prepare and present their findings to the class. Discussions were held on "What's the importance of mines in terms of a country's economy and development?" and "Why is it important for natural monuments to be recognized as part of our cultural heritage?" in the classroom.

\section{Result}

The findings from the concept test, drawing test, and interview questions were resented below. The Mann Whitney U-Test results were presented in Table 2.

Table 2. Results of the Mann Whitney U-test

\begin{tabular}{lllllll}
\hline Test & Groups & $\mathrm{n}$ & Mean Rank & Sum of Rank & $\mathrm{U}$ & $\mathrm{p}$ \\
\hline \multirow{2}{*}{ Pre test } & Experiment & 20 & 23,70 & 474,00 & \multirow{2}{*}{136,00} & \multirow{2}{*}{0,081} \\
\cline { 2 - 5 } & Control & 20 & 17,30 & 346,00 & & \\
\hline \multirow{2}{*}{ Post test } & Experiment & 20 & 26,70 & 534,00 & \multirow{2}{*}{76,00} & \multirow{2}{*}{0,001} \\
\cline { 2 - 5 } & Control & 20 & 14,30 & 286,00 & & \\
\hline
\end{tabular}

The study results indicated that there was no significant difference between the pre-test scores of the concept test conducted on the experiment and control group ( $U=136,00 \mathrm{p}>.05)$. There was a significant difference between the post test scores conducted on experiment and control groups in favour of the experiment group $(U=76,00, p<.05)$. Table 3 shows analysis of the questions in the concept test. 
Table 3. Frequency distribution of the responses in the concept test

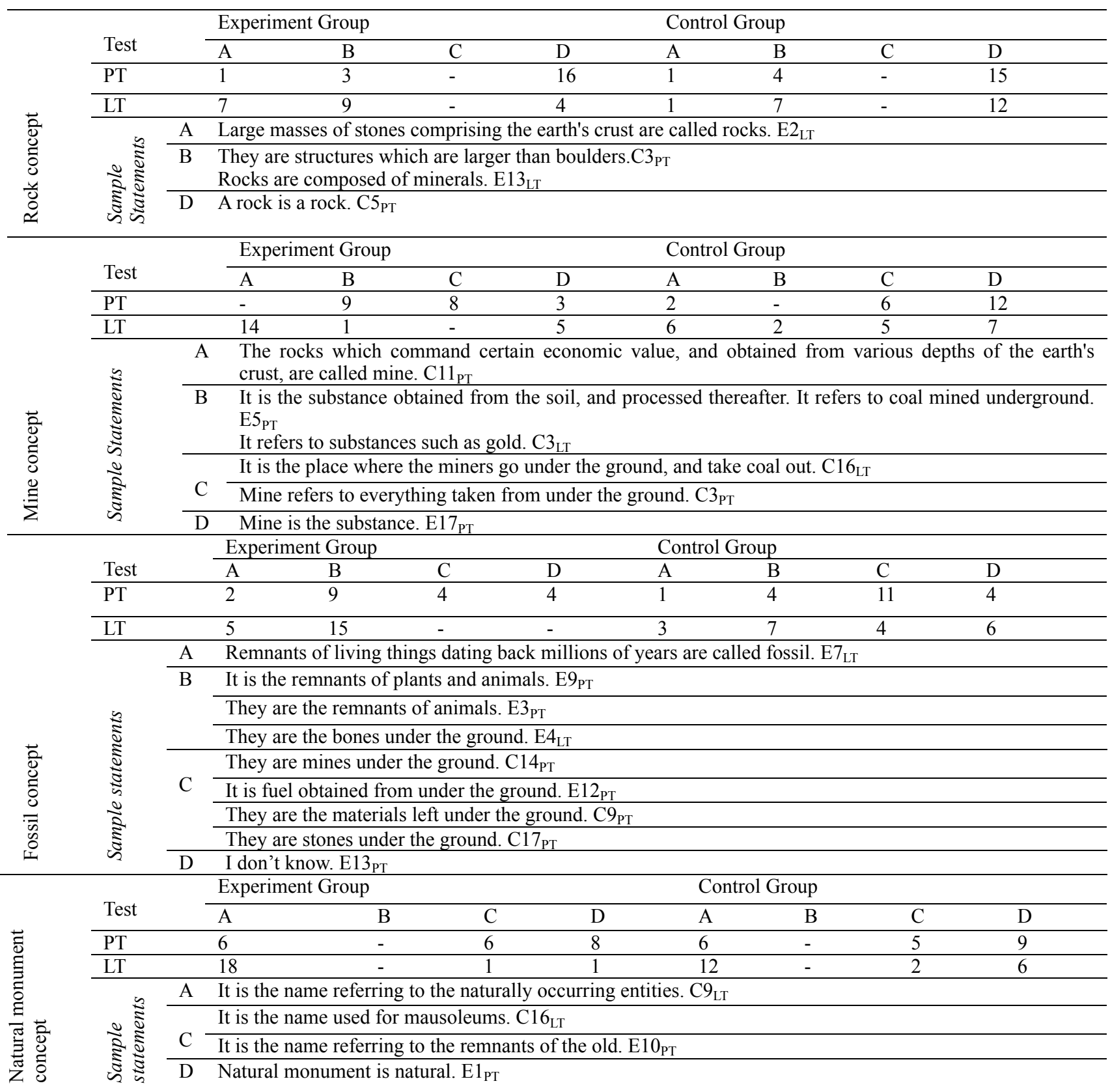

PT: Pre-test, LT: Post-test, A: Complete understanding, B: Partial understanding; C: Alternative concept, D: No response or irrelevant responses

In the pre-test, 3 students from the experimental group and 4 from the control group provided partial definitions of the concept of rocks. In the pre-test, the number of students who failed to provide an answer to the question, or who provided unrelated answers, were very high. The review of the post-test results revealed that the vast majority of the students in the experimental group had provided correct or partly-correct answers to the question. In the post-test, 12 students from the control group did not answer the question, while 8 provided correct or partly-correct answers.

In the pre-test, 8 students from the experimental group and 6 from the control group provided alternative definitions of the concept of mine. A review of Table 3 revealed that the misconceptions about the term mine are "Place where miners go under the ground and take coal out", and "Everything taken from under the ground" branches. Table 3 revealed that the most widely-voiced misconception among the students about the concept of fossils was worded as "the fuel obtained from under the ground."

During the pre-test, that misconception was voiced by 4 of the students in the experimental group, and 11 from the control group. The misconceptions voiced by the students were worded as "They are the materials left under the 
ground", "They are mines under the ground", and "They are stones under the ground". The review of the responses students provided in the post-test with regard to this question showed that the experimental group enjoyed better results in terms of the number of students in the complete and partial-understanding categories.

Table 3 showed that, in the pre-test, 6 students from the experimental group and 6 from the control group provided complete understanding responses related to the natural monument concept. In both groups, the number of students who failed to provide an answer was significant. The misconceptions voiced by the students were found to converge in the forms "It is the name used for mausoleums" and "It is the name referring to the remnants of the old". In the post-test, on the other hand, 18 students from the experimental group and 12 from the control group provided complete understanding responses to the question about the concept, noting "It is the name referring to the naturally occurring entities". The data regarding the interview questions were presented in Table 4.

Table 4. Categorization of the responses to the interviews

\begin{tabular}{|c|c|c|}
\hline Ct. & Concepts & Sample Statements \\
\hline \multirow[t]{4}{*}{ A } & Rock & $\begin{array}{l}\text { Large masses of stones comprising the earth's crust are called rocks. } \\
\mathrm{E} 2_{\mathrm{LI}}\left(\mathrm{E} 3, \mathrm{E} 6, \mathrm{E} 8, \mathrm{E} 13, \mathrm{E} 16, \mathrm{E} 17_{\mathrm{LI}}\right)\end{array}$ \\
\hline & Mine & $\begin{array}{l}\text { The name used to denote substances of economic value, obtained } \\
\text { from under the ground. } \mathrm{E} 16_{\mathrm{LI}}\left(\mathrm{E} 2,3,6,8,10,13,17_{\mathrm{LI}}\right)\end{array}$ \\
\hline & Fossil & $\begin{array}{l}\text { They are remnants of living things which had remained under the } \\
\text { ground millions of years ago, to reach us. E6 } 6_{\mathrm{PI}}\left(\mathrm{E} 6,17_{\mathrm{PI}} \mathrm{E} 3,6,13,14 \text {, }\right. \\
\left.16,17,19_{\mathrm{LI}}\right)\end{array}$ \\
\hline & $\begin{array}{l}\text { Natural } \\
\text { monument }\end{array}$ & It is the name referring to naturally occurring structures. $\mathrm{E} 3_{\mathrm{PI}}\left(\mathrm{E} 17_{\mathrm{PI}}\right)$ \\
\hline \multirow[t]{4}{*}{ B } & Rock & $\begin{array}{l}\text { The structures composed of minerals are called rocks. E8 } 8_{\mathrm{PI}}(\mathrm{E} 6,10 \text {, } \\
\left.13,19_{\mathrm{PI}} \mathrm{E} 10,14,19_{\mathrm{LI}}\right)\end{array}$ \\
\hline & Mine & The coal taken from under the ground. E13 $3_{\mathrm{PI}}\left(\mathrm{E} 2,6,8_{\mathrm{PI}}-\mathrm{E} 14,19_{\mathrm{LI}}\right)$ \\
\hline & Fossil & $\begin{array}{l}\text { It refers to the case where dinosaur bones are preserved at the site } \\
\text { where they died. } \mathrm{E} 14_{\mathrm{PI}}\left(\mathrm{E} 16_{\mathrm{PI}}\right)\end{array}$ \\
\hline & & $\begin{array}{l}\text { It refers to the remnants formed after the death of animals and plants. } \\
\mathrm{E} 8_{\mathrm{PI}}\left(\mathrm{E} 2,8,10_{\mathrm{LI}}\right)\end{array}$ \\
\hline \multirow[t]{8}{*}{$\mathrm{C}$} & Rock & They are small pieces of stone. E14 $4_{\mathrm{PI}}\left(\mathrm{E} 16,17_{\mathrm{PI}}\right)$ \\
\hline & Mine & It refers to everything taken from under the ground. \\
\hline & & $\mathrm{E} 3_{\mathrm{PI}}\left(\mathrm{E} 16_{\mathrm{PI}}\right)$ \\
\hline & & $\begin{array}{l}\text { The place where laborers work under the ground, and get their faces } \\
\text { black in an effort to get coal. E14 } 4_{\mathrm{PI}}\left(\mathrm{E} 10,19_{\mathrm{PI}}\right)\end{array}$ \\
\hline & Fossil & Non-living things also can turn into fossils. $\mathrm{E} 13_{\mathrm{PI}}\left(\mathrm{E} 3_{\mathrm{PI}}\right)$ \\
\hline & & $\begin{array}{l}\text { It is petroleum. Petroleum is obtained from under the ground. } \\
\text { Petroleum is a type of fossil. E2 } 2_{\mathrm{PI}}\left(\mathrm{E} 10_{\mathrm{PI}}\right)\end{array}$ \\
\hline & $\begin{array}{l}\text { Natural } \\
\text { monument }\end{array}$ & $\begin{array}{l}\text { They are places of immense value for us, such as the Anitkabir. } \\
\text { E16 } \mathrm{PI}\end{array}$ \\
\hline & & It is the name referring to the remnants of the old. E10 $0_{\mathrm{PI}}\left(\mathrm{E} 19_{\mathrm{PI}}\right)$ \\
\hline \multirow[t]{4}{*}{$\mathrm{D}$} & Rock & No idea $\left(\mathrm{E} 2,3_{\mathrm{PI}}\right)$ \\
\hline & Mine & I think of water when someone says mine. $\mathrm{E} 17_{\mathrm{PI}}$ \\
\hline & Fossil & I don't know. E199 \\
\hline & $\begin{array}{l}\text { Natural } \\
\text { monument }\end{array}$ & I don't know. (E2, 6, 8, 13,14,8 $\left.8_{\mathrm{PI}}\right)$ \\
\hline
\end{tabular}

PI: Pre Interview; LI: Post Interview; Ct:Categories

Table 4 depicted that in the preliminary interviews, 3 students indicated misconceptions in terms of considering rocks as being small pieces of stone. In the post-interviews, the students were observed to have eliminated such misconceptions, 
and to provide answers which can be considered in the partial and complete comprehension categories. Answers by 2 of the students on the concept of mine, were presented in Table 4 as "It refers to everything taken from under the ground." Three more students said "The place where laborers work under the ground, and get their faces black in an effort to get coal" thereby exhibiting substantial misconceptions. In the post-interviews, the students were observed to have eliminated such misconceptions, and most provided answers which could be considered to be in the complete comprehension category. Table 4 revealed that the most commonly-voiced misconceptions about the concept of fossils were in the veins of "It is petroleum. Petroleum is obtained from under the ground; petroleum is a type of fossil" and "Non-living things also can turn into fossils". In post-interviews the vast majority of the students were found to provide either fully-correct or partially-correct answers. Table 4 indicated that in the pre-test, 3 students voiced their misconceptions. These students were found to have misconceptions such as: "They are places of immense value for us, such as the Anttkabir." and "It is the name referring to the remnants of the old". The frequency of categories observed in the drawings provided by the students on the concept of fossils is presented in Table 5 .

Table 5. Frequencies and codes of the findings obtained from the drawing test*

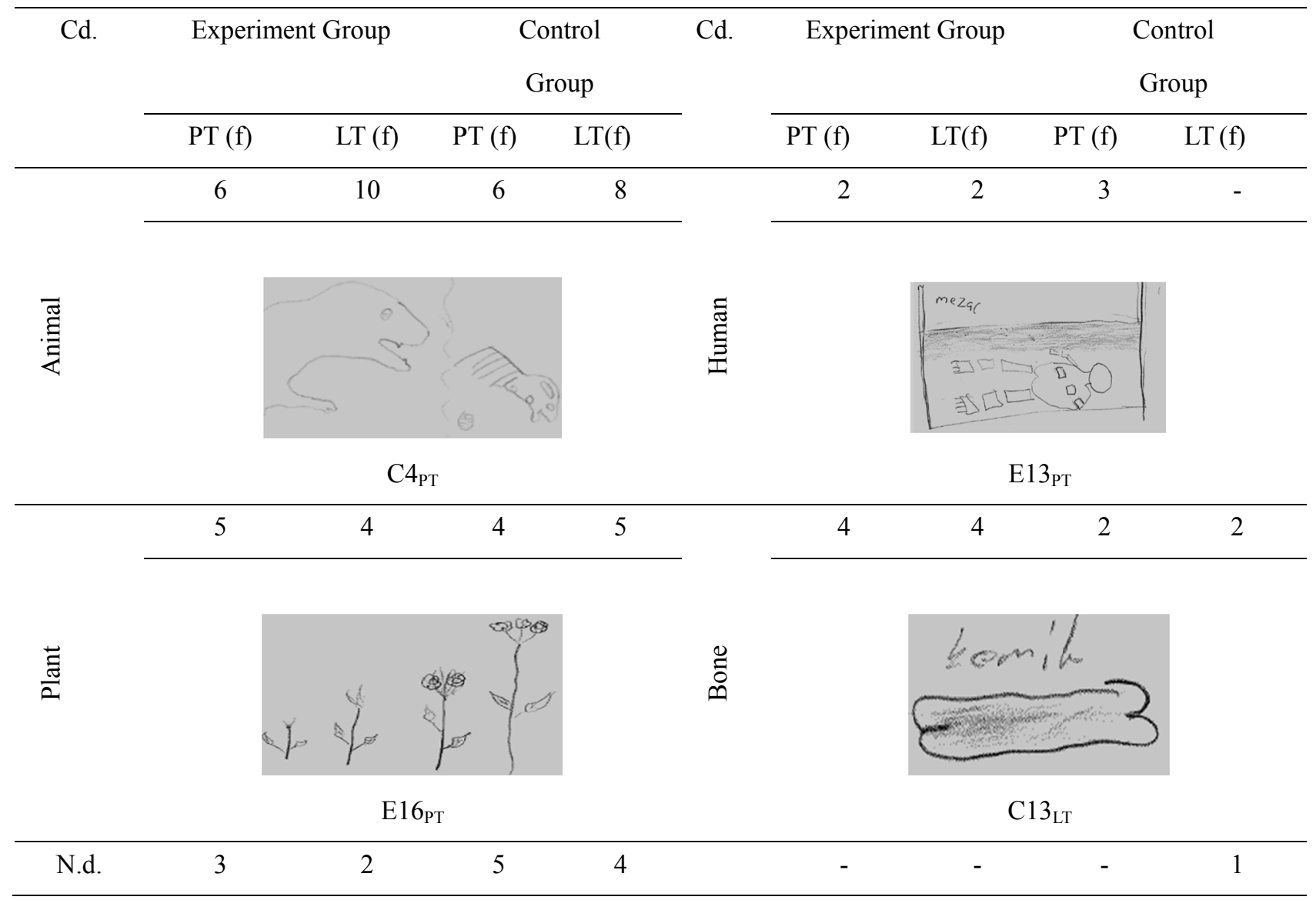

Cd. Codes; N.d.:No drawing *Some students draw more than one code.

Table 5 suggests that, in the pre-test, students from both the experimental and the control groups made drawings incorporating animals, plants, humans, and bones to depict the concept of a fossil. The vast majority of the students from both groups drew animal figures to depict the concept. In drawing animal figures, in turn, they showed a marked preference for dinosaurs. In the post-test, the vast majority of the students provided drawings once again utilizing animals to depict the concept of fossils. As a cursory glance at table 5 will reveal, the overwhelming majority of the students used dinosaurs in terms of all animals. Table 6 below presents the frequency distribution of the data obtained from the drawings on the concept of natural monuments as provided by the students. 
Table 6. Frequencies and codes of the findings obtained from the drawing test*

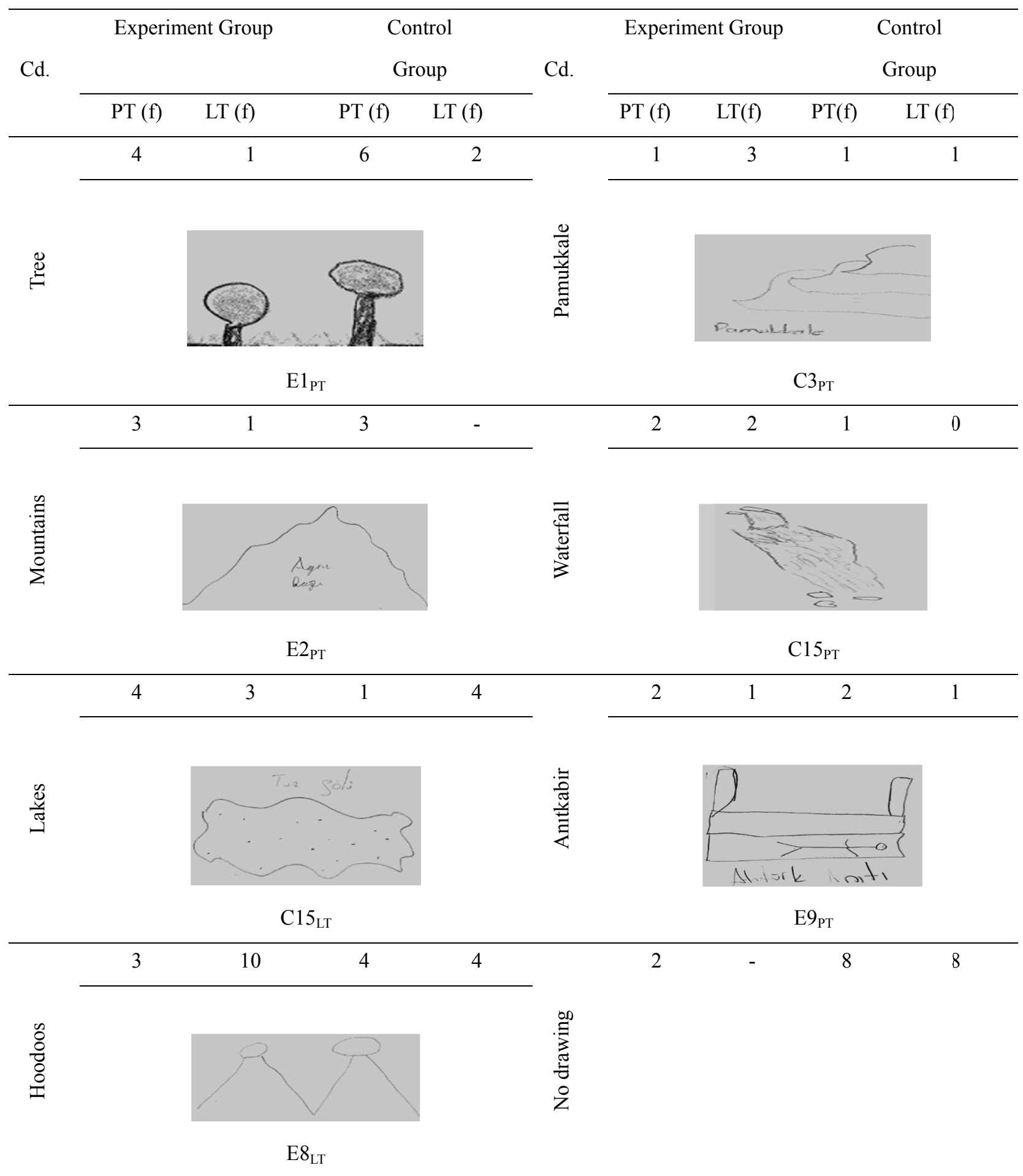

*Some students draw more than one code.

As depicted in Table 6, in the pre-test, students tended to go with trees, mountains, lakes, hoodoos, Pamukkale, waterfalls, and Anitkabir when asked to draw a natural monument. In the pre-test, 4 of the students in the experimental group, and 6 from the control group, drew trees to describe the concept of natural monuments.

\section{Discussion and Conclusions}

The review of the results of the pre-test taken by the students in the experimental and the control groups, on the topic "What is the Earth's Crust Composed of?" (Table 2) depicted one of the study findings that no significant difference existed between the pre-test scores of each group, in terms of conceptual understanding ( $U=136.00 \mathrm{p}>.05)$. The lack of 
a significant difference among the concept test scores of each group, in turn, can serve as proof that the students had similar levels of preliminary information on the topic "What is the Earth's Crust Composed of?". On the other hand, the post-test results exhibited a significant difference favoring the experimental group ( $\mathrm{U}=76.00 \mathrm{p}<.05)$. Students' scores in the post-test suggested that the teaching with regard to the experiment group was more effective as it contributed to the conceptual understanding of the students. This is deemed to be related to the favorable effect of the enriched learning environment provided within the framework of the $5 \mathrm{E}$ model.

The teaching materials used with the experimental group were worksheets, case studies, and conceptual change texts. The case studies provided with reference to issues such as mines are believed to have contributed to the establishment of links between concepts and their daily lives. Burbules and Linn (1991) associated the students' inability to decipher the contexts they face in their daily lives with an inability to relate the knowledge learned at school to daily life applications and to different cases. Among the guidance materials, case studies are deemed to be particularly effective in terms of associating concepts with daily life. Özkan and Azar (2005) noted that a true story from daily life, discussed as a case, could facilitate the transfer of learning to daily life issues. Campbell and Lubnen (2000) emphasize the need to establish a link between the concepts and current events, in order to make a permanent mark with regard to the concepts taught, on students' minds. The conceptual change texts used within the framework of the study contributed to conceptual development on the part of the students. For instance, some students believed that only animals were able to fossilize. The conceptual change texts used to relay the concept had perhaps contributed to the elimination of such misconceptions among the students. The existing literature is not bereft of studies revealing the effectiveness of conceptual change texts in terms of doing away with the misconceptions harbored by the students (Cerit, Berber \& Sar1 2009; Uzuntiryaki \& Geban 2005; Chambers \& Andre 1997). The earth's crust is composed of rocks, stones and soil. Rocks are the large masses of stone that constitute the earth's crust. As rocks become eroded due to a number of factors, boulders and stones are formed. The statements along the lines of "they are small pieces of stone" provided by the students in the preliminary interviews suggested the existence of confusion with regard to the terms rock and stone. However, the post-test showed that such misconceptions were eliminated. In a similar fashion, the students in the experimental and control group were found to refer exclusively to coal mines when it came to describing the concept of mines in the pre-test (Tables 3). The statement provided by student E14, "The place where laborers work under the ground, and get their faces black in an effort to get coal" is evidence of this tendency. The association students made between the concept of a mine and the place where coal is mined, has perhaps something to do with Turkey being one of the top ten countries in terms of coal reserves. Coal mines are pretty widespread in Turkey.

The review of the responses provided by the students from the experimental and the control groups, about the concept of fossils revealed that, in the pre-test, the students exhibited some misconceptions, using the terms "fossil" and "fossil fuel" interchangeably. The answers provided by the students in the interviews presented some misconceptions, worded as "non-living things can turn into fossils as well" and "It is petroleum. Petroleum is obtained from under the ground. It is a kind of fossil". The results of the post-test, on the other hand, showed that the vast majority of the students were free of such misconceptions. The drawings provided by the students about the concept of fossils show that most focused on the animal category (Table 5). The detailed review of the drawings in that category, in turn, revealed a preference for dinosaur illustrations. This may be associated with the fact that dinosaur fossils are frequently used as examples of fossils shown in books. The views voiced, and the drawings provided by the students with respect to the concept of natural monuments (Tables 4, 6), reveal that the students were not very familiar with the concept of natural monuments. Guidance material is deemed to be effective in terms of the significant difference observed between the conceptual comprehension levels of the experimental group and those of the control group.

Conceptual change text studies helped in eliminating misconceptions among the students (Er Nas, Çalık \& Çepni, 2012; Beerenwinkel, Parchmann \& Grasel, 2011; Sarı Ay \& Aydoğdu, 2015). Case studies relating to the association of concepts with daily life contributed students' conceptual understanding (Dori, Tal \& Tsaushu 2003; Özkan \& Azar, 2005; Hartfield, 2010). Worksheets helped in the reinforcement of learning among students working in groups, This is why the inclusion of case studies, worksheets, and conceptual change texts in textbooks is expected to contribute significantly to conceptual comprehension on the part of the students. Research results have demonstrated that, guidance material have a positive effect in the learning associated with the topic "What is the earth's crust composed of?". The learning environment should have been enriched with conceptual understanding text, worksheets, and case studies. The drawings provided by the students about the concept of fossils showed that most of them focused on the animal category in this study. Therefore textbooks should have included different fossil examples in addition to animals.

\section{References}

Alım, M., Özdemir, Ü., \& Yılar, B. (2008). The perceptions levels of the geography concepts and the misconception of the 5th year students. Atatürk University Journal of Graduate School of Social Sciences, 11(1), 151-162. 
Anil, Ö., \& Batdi, V. (2015). A comparative meta-analysis of 5E and traditional approaches in Turkey. Journal of Education and Training Studies, 3(6), 212-219. http://dx.doi.org/10.11114/jets.v3i6.1038.

Ateş, M. (2013). A research on high school students' concepts of "erosion" by using phenomenographic analysis. Educational Research and Reviews, 8(9), 449-453. http://dx.doi.org/10.5897/ERR2013.1425.

Barker, V., \& Millar, R. (1999). Students' reasoning about chemical reactions: what changes occur during a context-based post-16 chemistry course? International Journal of Science Education, 21(6), 645-665. http://dx.doi.org/10.1080/095006999290499

Bayram, G., \& Kibar, F. S. (2014). Elementary science 5th textbook. Ankara: Sevgi Publishing, Retrieved from http://www.eba.gov.tr/ekitapdetay/2608 (31.07.2015)

Beerenwinkel, A., Parchmann, I., \& Grasel, C. (2011). Conceptual change texts in chemistry teaching; a study on the particle model of matter. International Journal of Science and Mathematics Education, 9(5), 1235-1259. $\mathrm{http}: / / \mathrm{dx}$. doi.org/10.1007/s10763-010-9257-9.

Blake, A. (2004). Helping young children to see what is relevant and why: supporting cognitive change in earth science using analogy. International Journal of Science Education, 26(15), 1855-1873. http://dx.doi.org/10.1080/0950069042000266173

Blake, A. (2005). Do young children's ideas about the earth's structure and processes reveal underlying patterns of descriptive and causal understanding in earth science? Research in Science \& Technological Education, 23(1), 5974. http://dx.doi.org/10.1080/02635140500068450

Bozkurt, O., Salman, A. B., \& Uşak, M. (2004). Identifying of grade 6, 7. and 8. students' pre-information and misconceptions about the erosion. Journal of Kırşehir Education Faculty, 5(2), 277-285.

Burbules, N. C., \& Linn, M. C. (1991). Science education and philosophy of science: congruence or contradiction?. International Journal of Science Education, 13(3), 227-241. http://dx.doi.org/10.1080/0950069910130302

Büyüköztürk, Ş. (2004). Data analysis handbook for social sciences. Ankara: PegemA Publication.

Campbell, B., \& Lubben, F. (2000). Learning science through contexts: helping pupils make sense of everyday situations. International Journal of Science Education, 22(3), 239-252. http://dx.doi.org/10.1080/095006900289859.

Çardak, O., Dikmenli, M., \& Saritas, O. (2008). Effect of 5E instructional model in student success in primary school 6th year circulatory system topic. Asia-Pacific Forum on Science Learning and Teaching, 9(2), 1-11.

Cerit Berber, N., \& Sar1, M. (2009). Effectiveness of conceptual change texts in understanding work-power-energy subject. Selçuk University Journal Of Ahmet Keleşoğlu Education Faculty, 27, 159- 172.

Chambers, S. K., \& Andre, T. (1997). Gender prior knowledge, interest and experience in electricity and conceptual change text manipulations in learning about direct current. Journal of Research in Science Teaching, 34(2), 107-123. http://dx.doi.org/10.1002/(SICI)1098-2736(199702)34:2<107::AID TEA2>3.0.CO;2-X

Dal, B. (2007). Fossil teaching. Hacettepe University Journal of Education, 32, 52-64.

Dal, B. (2009). An investigation into the understanding of earth science among students' teachers. Educational Sciences: Theory \& Practice, 9(2), 597-606.

Demirel, Ö. (2014). Program development from theory to practice. Ankara: PegemA Publication.

Dervişoğlu, S., Yaman, M., \& Soran, H. (2004). Evaluating the interest of high school students in lessons. Hacettepe University Journal of Education, 27, 67-73.

Dori, Y. J., Tal, R. T., \& Tsaushu, M. (2003). Learning and assessing biotechnology topics through case studies with built-in dilemmas. Science Education, 87(6), 767-793.

Dove, J. (1997). Student ideas about weathering and erosion. International Journal of Science Education, 19(8), 971-980. http://dx.doi.org/10.1080/0950069970190809.

Duit, R. (1991). On the role of analogies and metaphors in learning science. Science Education, 75, 649-672. http://dx.doi.org/10.1002/sce.3730750606.

Er Nas, S., Çalık, M., \& Çepni, S. (2012). Effect of different change pedagogies embedded within 5E model on grade 6 students' alternative conceptions of 'heat transfer. Energy Education Science and Technology Part B: Social and Educational Studies, 4(1), 177-186.

Er, N. S., Şenel, Ç. T., \& Kirman, B. A. (2016). The effect of fire context on the conceptual understanding of students: "Expansion-contraction”. Educational Research and Reviews, 11(21), 1973-1985. 
Ford, D. J. (2005). The challenges of observing geologically: third graders' descriptions of rock and mineral properties. Science Education, 89(2), 276-295. doi:10.1002/sce.20049

Hançer, A. H. (2006). Enhancing learning though constructivist approach in science education. International Journal of Environmental and Science Education, 1(2), 181-188.

Harlen, W. (1996). The teaching of science in primary school. London: David Fulton Puplishers.

Hartfield, P. J. (2010). Reinforcing constructivist teaching in advanced level biochemistry through the introduction of case-based learning activities. Journal of Learning Design, 3(3), 20-31.

Küçükahmet, L. (2000). Planning and evaluation in teaching. Ankara: Nobel Publication.

Marek, E. A. (1986). They misunderstand, but they'll pass. The Science Teacher, 53(9), 32-35.

Ministry of National Education (MoNE). (2013). Science Curricula for grades 3-8. Ankara: Head Council of Education and Morality.

Özgen, N. (2013). Perception of pre-service teachers regarding the concept of erosion: A phenomenographic study. Hacettepe University Journal of Education, 28(2), 321- 334.

Özkan, M., \& Azar, A. (2005). The examination of effect to lesson achievement and lesson attitude of 9 th class students of educational method based on sample event. Journal of National Education, 168.

Özsevgeç, T. (2006). Evaluation of effectiveness of student guide material developed according to 5E model "Force and movement unit", Journal of Turkish Science Education, 3(2), 36-48.

Patro, E. T. (2008). Teaching aerobic cell respiration using the 5 Es. The American Biology Teacher, 70(2), 85-87. doi: http://dx.doi.org/10.1662/0002-7685(2008)70[85:TACRUT]2.0.CO;2

Reinfried, S. (2006). Conceptual change in physical geography and environmental sciences through mental model building: The example of groundwater. International Research in Geographical and Environmental Education, 15(1), 41-61.doi: $10.2167 /$ irgee 186.0

Rosenberg, S., Hammer, D. \& Phelan, J. (2006). Multiple epistemological coherences in an eighth-grade discussion of the rock cycle. The Journal of the Learning Sciences, 15(2), 261-292. http://dx.doi.org/10.1207/s15327809j1s1502_4

Şahin, Ç., İpek, A. H., \& Çepni, S. (2012). Teaching of solid pressure with animation, analogy and worksheet to primary 8th students. The Journal of Instructional Technologies \& Teacher Education, 1(1), $22-51$.

Sarı, A. Ö., \& Aydoğdu, C. (2015). The effect of conceptual change texts in the misconceptions identified removal in the unit of states of matter and heat. Hacettepe University Journal of Education, 30(2), 99-111.

Şenel, Ç. T., Kirman, B. A., \& Er, N. S. (2016). The effect of enriched learning environments on the conceptual understanding of students: "The erosion and landslide". Journal of Education and Training Studies, 4(10), 248-260.

Sheppard, K. (2006). High school students' understanding of titrations and related acid-base phenomena. Chemistry Education Research and Practice, 7(1), 32-45. http://dx.doi.org/10.1039/B5RP90014J

Tharenou, P., Donohue, R., \& Cooper, B. (2007). Management research methods. New York: Cambridge University Press.

Treagust, D. F., Harrison, A. G., \& Venville, G. J. (1998). Teaching science effectively with analogies: an approach for preservice and inservice teacher education. Journal of Science Teacher Education, 9(2), 85-101.

Turan, İ., \& Kartal, A. (2012). The misconcepts of the fifth grade students on natural disasters. Journal of Kirşehir Education Faculty, 13(3), 67-81.

Uzuntiryaki, E., \& Geban, Ö. (2005). Effect of conceptual change approach accompanied with concept mapping on understanding of solution concepts. Instructional Science, 33(4), 311-339.

http://dx.doi.org/10.1007/s11251-005-2812-z

White, R., \& Gunstone, R. (1992). Probing understanding. London: Falmer Press.

Yager, R. E., \& Weld, J. D. (1999). Scope, sequence and coordination: The Iowa project, A national reform effort in The USA. International Journal of Science Education, 21(2), 169- 194. http://dx.doi.org/10.1080/095006999290778

\section{Copyrights}

Copyright for this article is retained by the author(s), with first publication rights granted to the journal.

This is an open-access article distributed under the terms and conditions of the Creative Commons Attribution license which permits unrestricted use, distribution, and reproduction in any medium, provided the original work is properly cited. 